OECDpublishing

STRUCTURAL

REFORMS AND

INCOME DISTRIBUTION

OECD ECONOMIC POLICY PAPER

April 2015 No. 13 


\section{Structural Reforms and Income Distribution}

This paper has been prepared by:

Orsetta Causa

Alain de Serres

Nicolas Ruiz

Authorised for publication by Catherine L. Mann, OECD Chief Economist and G20 Finance Deputy

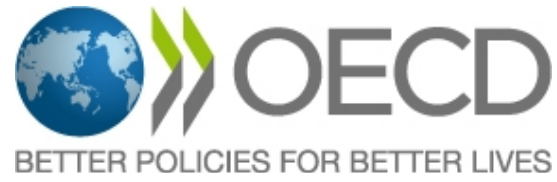


The OECD Economic Policy Paper Series is published on the responsibility of the Secretary-General of the OECD. The opinions expressed and arguments employed herein do not necessarily reflect the official views of the Organisation or of the governments of its member countries.

An earlier version of this paper was discussed at the Working Party No. 1 of the OECD Economic Policy Committee. The authors would like to thank the participants.

More detailed information is available from the following:

Causa, O., A. de Serres and N. Ruiz (2014), "Can growth-enhancing policies lift all boats? An analysis based on household disposable income", OECD Economics Department Working Papers, OECD Publishing, Paris.

Causa, O., S. Araujo, A. Cavaciuti, N. Ruiz and Z. Smidova, (2014) "A preliminary analysis of income distribution developments", OECD Economics Department Working Papers, No. 1111, OECD Publishing.

Series: OECD Economic Policy Papers

ISSN 2226583X

This document and any map included herein are without prejudice to the status of or sovereignty over any territory, to the delimitation of international frontiers and boundaries and to the name of any territory, city or area.

The statistical data for Israel are supplied by and under the responsibility of the relevant Israeli authorities. The use of such data by the OECD is without prejudice to the status of the Golan Heights, East Jerusalem and Israeli settlements in the West Bank under the terms of international law.

\section{(c) OECD 2015}

You can copy, download or print OECD content for your own use, and you can include excerpts from OECD publications, databases and multimedia products in your own documents, presentations, blogs, websites and teaching materials, provided that suitable acknowledgment of OECD as source and copyright owner is given. All requests for public or commercial use and translation rights should be submitted to rights@oecd.org. Requests for permission to photocopy portions of this material for public or commercial use shall be addressed directly to the Copyright Clearance Center (CCC) at info@copyright.com or the Centre français d'exploitation du droit de copie (CFC) at contact@cfcopies.com. 


\section{TABLE OF CONTENTS}

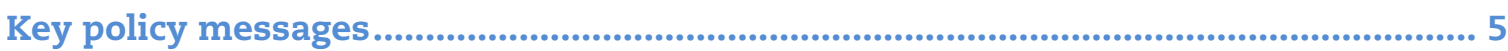

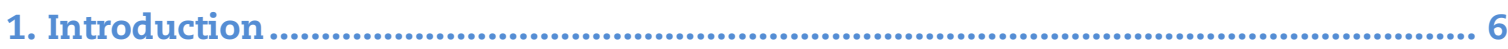

2. A unified framework for assessing households' material living standards on average and across the distribution.

3. Has GDP per capita growth trickled down to household disposable incomes across the distribution?................................................................................................ 11

4. The impact of structural policies on GDP per capita and household incomes across the distribution ..................................................................................................... 14

5. Which growth-enhancing policies have the potential to "lift all boats"? A Wrap-up and some illustrative simulations .............................................................. 27

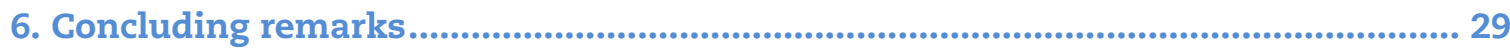

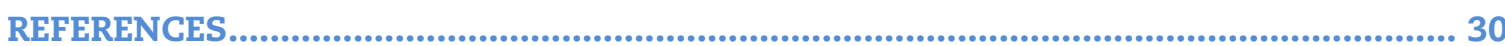

Tables

1. The effects of labour market and welfare policies on GDP per capita and household disposable incomes across the distribution

2. The effects of tax policy on GDP per capita and household disposable incomes across the distribution

3. The effects of product market regulation on GDP per capita and household disposable incomes across the distribution ................................................................ 22

4. The effects of up-skilling on GDP per capita and household disposable incomes across the distribution

5. The effects of up-skilling, technological progress and globalisation on GDP per capita and household disposable incomes across the distribution.

6. Wrapping-up: policy reforms to lift GDP per capita and household incomes, on average and across the distribution.

Figures

1. Household incomes across the distribution: selected OECD countries

2. Growth in household incomes across the distribution between the mid-90s and late 2000s: selected OECD countries

3. From GDP per capita to household disposable incomes across the distribution, baseline elasticities

Boxes

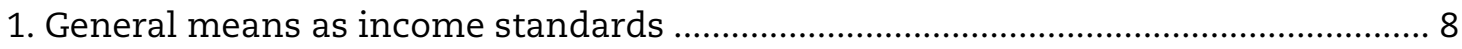

2. Overview of the baseline and policy-augmented models .......................................... 12 


\section{Abstract / Résumé}

\section{Structural reforms and income distribution}

This paper provides new empirical evidence on the effects of structural policies on household disposable incomes at different income levels. More specifically, it investigates the extent to which structural policies have differential long-run impacts on GDP per capita and on household incomes at different points of the distribution. One aim is to verify whether policy decisions may face tradeoffs between objectives of economic efficiency and equity. Many growth enhancing structural reforms are found to deliver stronger income gains for households at the lower end of the distribution compared with the average household, an indication that they may reduce inequality in disposable incomes. Such is the case of reducing regulatory barriers to domestic competition as well as to trade and FDI; stepping-up job-search support and activation programmes. Conversely, other reforms involve trade-offs between the efficiency and equity objective. This is the case of the tightening of unemployment benefits for the long-term unemployed, which is found to lift GDP per capita and average household incomes, but also to reduce disposable incomes at the lower end of the distribution.

JEL Classification codes: I3, J18, J3, J38, J6, D31, H2, H31, I24, C33

Keywords: income distribution, inequality, structural reforms, cross-country analysis

\section{Réformes structurelles et la distribution des revenus}

Cette étude presente des nouveaux résultats d'analyse empirique sur les effets des politiques structurelles sur le revenue dispoanible des ménages à differents niveaux de revenu. De manière plus spécifique, elle examine la mesure dans laquelle les politiques strucuturelles ont des impacts differents à long terme sur le PIB par habitant et le revenu des ménages, à différents points de la distribution. Un objectif consiste à vérifier si les choix de politiques impliquent des arbitrages entre les objectifs d'efficacité économique et ceux d'équité. Les résultats indiquent que plusieurs politiques favorables à la croissance entraînent des gains plus élevés pour les ménages qui se trouvent dans le bas de la distribution que pour les ménages situé autour de la moyenne, conduisant ainsi à une baisse des inégalités de revenus disponibles. C'est le cas notamment des mesures visant à réduire les barrières réglementaires à la concurrence domestique ainsi qu'au commerce extérieur et aux investissement étranger, de même que pour celles conduisant à un renforcement de l'aide à la recherche active d'emploi pour les chômeurs. À l'inverse, un resserement des indemnités chômage ciblé sur les chômeurs de longue durée réduit le revenue des ménages les plus modestes tandis qu'il entraîne une hausse du PIB par habitant et du revenu des ménages autour de la moyenne.

Classification JEL : I3, J18, J3, J38, J6, D31, H2, H31, I24, C33

Mots clés : Distribution des revenus, inégalité, réformes structurelles 


\section{Structural reforms and income distribution}

\section{Key policy messages}

- On average across OECD countries and between the mid-1980s and the late 2000s, growth in GDP per capita has not fully trickled down to household incomes. It has also been unequal, as growth in household disposable incomes has been weaker at the lower end of the income distribution. Aside from statistical issues, these trends could be due to economic factors reflected in increasing income transfers from the household to the corporate and public sectors:

- Measurement limitations include under-reporting of top incomes as well as noninclusion of capital gains in available survey-based household income data.

- Economic factors include a trend decline in the progressivity of tax and transfer systems, a rising share of GDP being distributed in the form of profits (as opposed to wages) and a growing share of profits being saved by corporations and re-distributed in the form of capital gains rather than interest or dividends.

- Growth-enhancing reforms can be distinguished according to whether they are found to generate an increase or a reduction in disposable income inequality:

- Many structural reforms are found to deliver stronger income gains for households at the lower end of the distribution. Such is the case of reducing regulatory barriers to domestic competition, trade and FDI, stepping-up job-search support and activation programmes and tightening unemployment benefits for all categories of jobseekers.

- Conversely, a tightening of unemployment benefits for the long-term unemployed only is found to lift GDP per capita and average household incomes but also to reduce disposable incomes at the lower end of the distribution, an indication that it may raise inequality.

- Reducing minimum relative to median wages is found to depress average and median disposable incomes, though not the income of households at the lower end of the distribution.

- While most growth-enhancing reforms benefit the median household, their effect on the median income does not coincide with their effect on GDP:

- Some reforms are found to raise median household income by more than GDP per capita: this is the case of a tightening of unemployment benefits for all categories of jobseekers or a lowering of labour taxation.

- Shifting from income to property or consumption taxes, boosting ICT investment and tightening unemployment benefits for the long-term unemployed raise median household income by less than GDP per capita. 
1. Introduction

In a majority of OECD countries, growth over the past three decades has been associated with growing disparities in household incomes suggesting that some of the forces driving GDP may have also fuelled inequalities. As a result, gains in household disposable incomes generally have not matched those in GDP per capita and the gap has been particularly large among poorer households and the lower-middle class. The present study provides new empirical evidence on the effects of structural policies on households' incomes across the distribution, with the aim of identifying potential policy tradeoffs and complementarities between efficiency and equity. ${ }^{1}$

The study first introduces a unified framework for analysing the profile and evolution of households' disposable income on average and across the distribution (section 2). ${ }^{2}$ It then examines the extent to which gains in GDP per capita have trickled down more or less equally to households across different income groups (section 3). New empirical evidence on the joint impact of structural reforms on GDP per capita and household disposable incomes at different points the distribution is presented (section 4). The implications in terms of the respective impacts on growth and income distrubution are summarised in the final section of the study (Section 5).

2. A unified framework for assessing households' material living standards on average and across the distribution

\subsection{Basic concepts and data limitations}

The central income concept used throughout the analysis is that of household real disposable income, as this is the best proxy of households' economic resources defined by internationally agreed standards and computable across the income distribution. ${ }^{3}$ Disposable income encompasses all income sources. It therefore includes net transfers from government (cash transfers net of direct taxes paid by households) in addition to market income, which covers both labour income (wages, salaries and self-employment income) and income derived from capital. Income is measured for total population and at the household level, taking into account economies of scale in consumption within households. ${ }^{4}$

The analysis relies on the OECD Income Distribution database, where an attempt is made to achieve comparability across countries and over time. ${ }^{5}$ Despite the high quality of the data, especially from a cross-country comparative perspective, some caveats need to be borne in mind to qualify the boundaries of the analysis:

1. Throughout the paper, more equity is to be interpreted as less income inequality without implying any judgement about the intrinsic value of a more equal distribution.

2. This study is a follow-up to an earlier descriptive paper which provided a new assessment of how households' income fared compared with GDP and of the evolution of inequality and poverty across OECD countries over the last fifteen years (Causa et al., 2014). Recent policy-oriented studies include OECD (2012) and OECD (2011b).

3. The notion that even from a narrow material living standard perspective GDP per capita falls short of accurately measuring people's wellbeing has been well documented. See Causa et al. 2014, Stiglitz et al, 2009, OECD, 2011a, OECD, 2010, 2013a, Boarini et al., 2006.

4. As is standard in inequality analysis, income measures are defined on an "equivalised" (or "per consumption unit") basis. The notion of "equivalisation" implies that the income attributed to each person in a household reflects income sharing within the household and adjusts for household needs. It is assumed that these needs increase with household size, but less than proportionally. A number of "scales" exist for such adjustment. In this analysis, total household income is divided by the square root of household size.

5. See Causa, de Serres and Ruiz (2014) and Causa et al. (2014) for more detailed discussions on data issues. 
- The study focuses on inequality from a static perspective. ${ }^{6}$ The data do not allow for measuring inequality in a dynamic perspective and therefore to study intra and intergenerational income mobility.

- The data measure income on a cash basis and therefore do not include several non-cash components such as in-kind public transfers, income for owner-occupied housing and capital gains. These income components are generally not evenly distributed across the income distribution. For example, in-kind public services represent a higher share of disposable incomes at the bottom of the distribution. ${ }^{7,8}$ The absence of in-kind public services implies that the current paper may overestimate the level of inequality in countries, such as Sweden, where such transfers represent a relatively important income component at the low end of the distribution - hence a major redistribution tool. Income from capital gains is likely to represent a higher share of disposable income at the top of the distribution and more generally in its upper-half. One associated risk is thus an underestimation of the level of inequality in countries where capital gains represent a relatively important income component for households in the upper-end of the distribution.

- As in most household surveys, the data used here may underestimate top incomes, reflecting a number of well-known factors such as non-response rates increasing with income levels or confidentiality issues. ${ }^{9}$

- Indirect taxes are not included in the measure of taxes paid by households. Their impact may tentatively be reflected in cross-country-time series differences in consumption prices faced by households. However, in this study real incomes are derived from the implicit assumption that all consumers across the income distribution face the same price for their consumption basket, as because price indices differentiated by population groups are not available for most countries. As a result, the data do not allow for addressing the distributional implications of e.g. consumption taxes.

\subsection{Household incomes across the distribution: the average and distribution-sensitive income standards}

This study builds on the approach developed by Foster and Szekely (2008) to derive headline household-based income standards indicators that allow for assessing different characteristics of the income distribution within a unified framework. In general, income standards are functions that summarise the income distribution by a single "representative" level of income, which can then be used in comparison of material living standards across countries and over time. Widely-used income standards reflect the general affluence of the distribution - the case of the average - or the affluence of some parts of the distribution - the case e.g. of the average income in the lowest quintile. The income standards used in this paper are based on the general mean approach which does not restrict attention to income below or above an arbitrary cut-off point while ignoring incomes beyond these thresholds. Instead, they use the information from the entire distribution but vary the weights so as to put more emphasis on incomes higher up or down the distribution, such

6. See Causa and Johansson (2011) for a study on intergenerational social mobility across OECD countries.

7. See Table 8.1 in OECD (2011b)

8. The distributive patterns of imputed rents are likely to vary across countries reflecting different estimation methods and also different institutional settings. See Törmälehto and H. Sauli (2010).

9. A more accurate assessment of top incomes would require the use of tax return data, as has been done in recent studies such as Chapter 9 in OECD (2011b), covering 17 OECD countries, which is based mostly on pre-tax income data compiled by Atkinson et al. (2011). There is evidence of the rise in top income shares in the three decades before the crisis for certain OECD countries, especially in the United States and, to a much lesser extent, Canada and the United Kingdom. See more recent work by Piketty (2013). 
as from top to average incomes, from average to median incomes, from median to bottom incomes (Box 1).

\section{Box 1. General means as income standards}

General means are grounded in Atkinson's (1970) framework for inequality and welfare analysis. Formally, general means are defined as follows:

$$
\mu_{\alpha}=\left[\left(x_{1}^{\alpha}+\ldots+x_{n}^{\alpha}\right) / n\right]^{\frac{1}{\alpha}} \text { for all } \alpha \neq 0 \text { and } \mu_{\alpha}=\left[\left(x_{1} \ldots x_{n}\right)\right]^{\frac{1}{n}} \text { for all } \alpha=0,
$$

where the vector $\mathrm{x}=\left(\mathrm{x}_{1, \ldots} \mathrm{x}_{\mathrm{n}}\right)$ describes the income distribution, $\mathrm{x}_{\mathrm{i}}>0$ is the income of the $\mathrm{i}$-th person and $\mathrm{n}$ is the population size.

For a fixed distribution $\mathrm{x}$, the value of the general mean $\mu \alpha(\mathrm{x})$ is increasing in the parameter $\alpha$. The income standard $\mu \alpha(\mathrm{x})$ places greater weight on higher incomes and less weight on lower incomes as the parameter rises. Hence $\alpha$ can be interpreted as (an inverse) measure of the level of inequality aversion. The parameter value $\alpha=1$ (corresponding to the average) provides a natural dividing line between the "bottom sensitive" income standards (with $\alpha<1$ ) that emphasise lower incomes and take values below the average, and "top sensitive" income standards (with $\alpha>1$ ) that emphasise higher incomes and take values above the average.

Inspection of income standard as defined by general means allows for a broad assessment of inequality across countries and over time. Because these functions can be linked to the Lorenz criterion underlying inequality measurement, this assessment will be consistent with that implied by most widely used summary inequality measures such as the Gini coefficient ${ }^{1}$ - and can be intuitively explained with the following properties: i) comparing income distributions across two countries (A and B) at a given point in time, if country $A$ and country B feature the same level of average income but all bottom sensitive income standards are lower and all top sensitive income standards are higher in country A, then this implies higher inequality in A compared with $\mathrm{B}$, consistent with Gini-based inequality ranking; ii) comparing income distributions in a single country over a given period: weaker growth in all bottom sensitive income standards and stronger growth in all top sensitive income standards compared with the average implies an increase in inequality over this period, consistent with Gini-based inequality assessment.

While this study starts by assessing the full-range of bottom to top-sensitive income standards, as governed by the parameter $\alpha$, the range of income standards considered is narrowed for policy analysis. The policy analysis is performed for average income and a selected range of bottom-sensitive income standards. From a welfare and policy perspective, these reflect increasing levels of inequality aversion, from no inequality aversion $(\alpha=1)$ to strong inequality aversion:

1. Null emphasis on the income distribution: the standard mean ( $\alpha=1$, average income) provides the benchmark point.

2. Weak emphasis on the bottom of the distribution: the geometric mean ( $\alpha=0$, median income) is empirically close to the median.

3. Moderate emphasis on the bottom of the distribution: this intermediate case $(\alpha=-3$, income of the lower-middle class) can be interpreted as covering incomes in the "lower-middle class", defined as households with incomes above the poverty threshold but below the median income.

4. Strong emphasis on the bottom of the distribution: this case $(\alpha=-8$, income of the poor) is empirically generally close to the mean income of the poor, where the latter are defined in relative terms with a threshold set between 50 and $60 \%$ of median income.

1. The Gini coefficient is defined as the area between the Lorenz curve (which plots cumulative shares of the population, from the poorest to the richest, against the cumulative share of income that they receive) and the $45^{\circ}$ line, taken as a ratio of the whole triangle.

Income standards as defined above can be used to evaluate and compare income distributions across countries and over time. First, inspection of income standard curves delivers a broad assessment of inequality rankings across countries, which will be consistent with that implied by most widely-used summary measures of inequality such as the Gini coefficient. This evaluation is illustrated in Figure 1 for selected pairs of OECD countries, with similar levels of average household incomes in 2010. Panel A compares the United States with Norway: for a common level of average income, all bottom-sensitive income standards are lower for the United States than for Norway, 
whereas all top-sensitive income standards are higher, clearly indicating the lower level of income inequalities in the latter country compared with the former.

In addition, income standard curves provide, in a snapshot, the "location" and profile of inequality within countries at any given point in time. For example, contrasting with the previous case showing strong distributional differences for top and bottom-sensitive income standards, a comparison between Sweden and the United Kingdom points to strong distributional differences for top-sensitive income standards only (Figure1, Panel B). This indicates that the higher level of income inequalities in the United Kingdom compared with Sweden is mostly driven by higher inequality within the upper half of the distribution.

Figure 1. Household incomes across the distribution: selected OECD countries
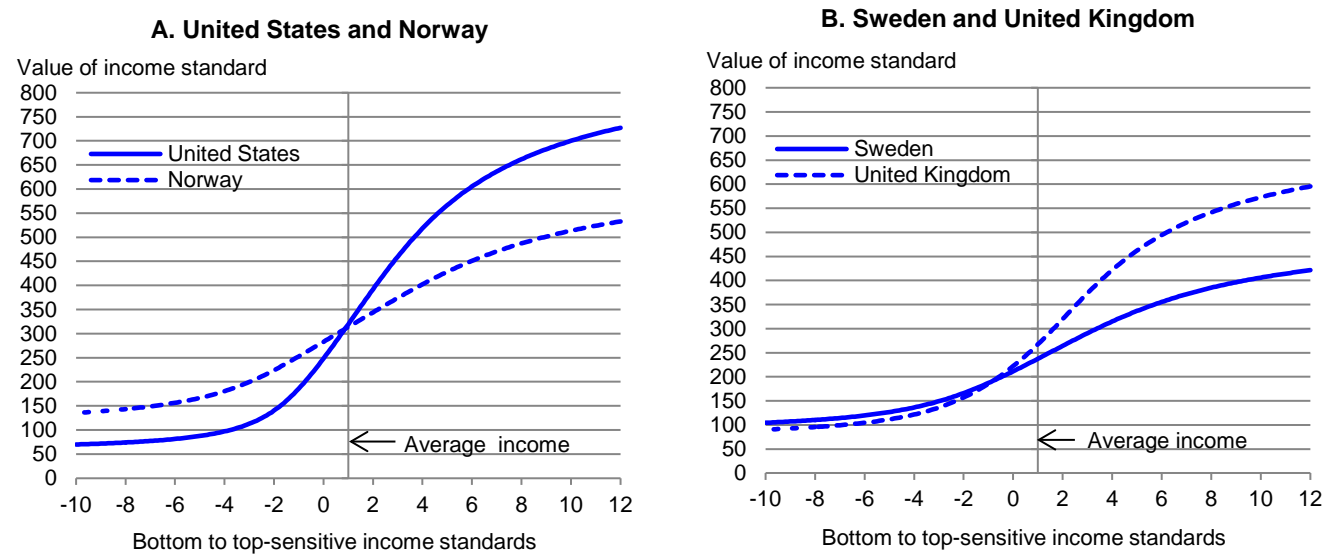

StatLink 제교 http://dx.doi.org/10.1787/888933129866

Note: As explained in the text, household incomes across the distribution are measured by the full range of income standards, i.e. from top to bottom-sensitive income standards. Income data refer to 2010 and are divided by a factor of 100 and expressed in USD, constant prices and constant PPPs (OECD base year 2005) with Purchasing Power Parities for private consumption of households.

The figures read as follows. Panel A compares the United States to Norway: for a common level of average income, all bottom-sensitive income standards $(\alpha<1)$ are lower for the United States than for Norway, whereas all top-sensitive income standards $(\alpha>1)$ are higher, indicating the lower level of income inequalities in the latter country compared with the former.

See text for details.

Source: OECD Income Distribution Database.

The comparison between growth in bottom to top-sensitive income standards and growth in mean incomes provides a broad assessment of inequality developments, and, again this assessment will be consistent with that implied by the Gini coefficient. This evaluation is illustrated in Figure 2 (Panels A and B) for selected pairs of OECD countries, in each case exhibiting similar growth of average household income over the period going from the mid-90s to end-2000s (i.e. the income standard curves cross at $\mu_{1}$ ). Panel A compares Sweden with Turkey: in Turkey all bottom-sensitive income standards grew much faster than the average, whereas top-sensitive income standards grew more slowly, implying a marked decline in inequality. In Sweden, the opposite occurred, implying a sharp increase in inequality.

Growth in income standards allows not only for assessing the broad evolution of inequality but also associated profiles, i.e. the sources and patterns of changing inequality within each country. For example, the contrasting developments in inequality between Sweden and Turkey were driven by growth differences in both the upper and lower halves of the income distribution, that is, for both top and bottom sensitive income standards compared with the average. In the case of Belgium and the United States (Figure 2, Panel B), the broad divergence in inequality - a decline in the former country and a rise in the latter- was mainly driven by differential developments within the lower half of the income distribution. The data would suggest for instance that the rise in inequality in the 
United States between the mid-90s and the end-2000s resulted from a marked growth shortfall of bottom compared to middle incomes amid similar growth dynamics within the upper-half of the income distribution. ${ }^{10}$

Finally, Spain provides a good illustration of contrasting inequality developments in the two halves of the distribution (Figure 2, Panel C): it experienced lower growth in top-sensitive income standards compared with the middle of the distribution, implying contracting inequalities in the upper-half of the income distribution, but at the same time slower (in fact negative) growth in bottom-sensitive income standards compared with the middle of the distribution, implying increasing inequalities in the middle and lower half of the income distribution. According to the Gini coefficient, income inequality declined over that period in Spain, suggesting that summary inequality measures on their own provide a partial view of inequality developments.

To summarise, income standards deliver, within a single curve, a comprehensive assessment of countries' income distribution and provide a powerful complement to standard inequality analysis derived from single measures such as the Gini coefficient or income shares. For instance, designing appropriate policies to reduce the level or curb the rise in inequality can be helped by prior identification of the profile of inequality at one point in time or with reference to the past. Whether inequality increases occurred across the whole distribution of income (such as in Sweden) or within a narrower part of the distribution (such as in the United States and even more so in Spain) would bear differential policy implications such as e.g. increasing top marginal tax rates versus introducing tax credits for low incomes.

10. However, this should be qualified due to the risk that the data used here may underestimate the increase in upper-income inequalities in the United States. As stated above, this results from the low coverage of top incomes in household surveys along with the large increases in their income shares over the last three decades compared with the rest of the OECD for which data are available. 
Figure 2. Growth in household incomes across the distribution between the mid-90s and late 2000s: selected OECD countries

\section{A. Sweden and Turkey}

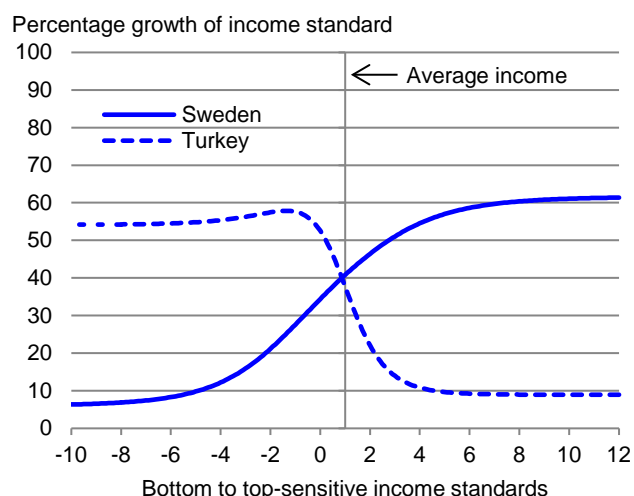

B. United States and Belgium

Percentage growth of income standard

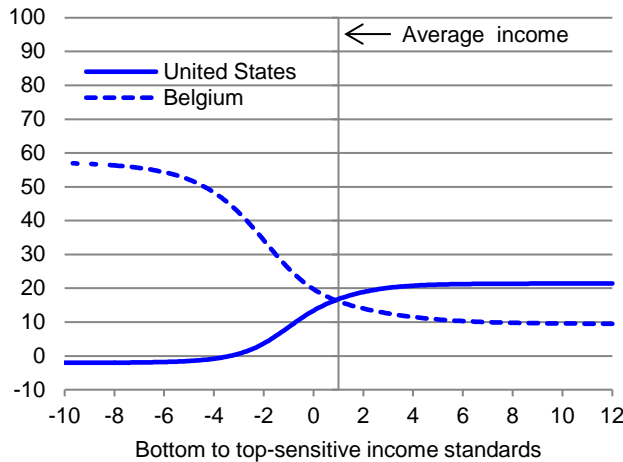

C. Spain

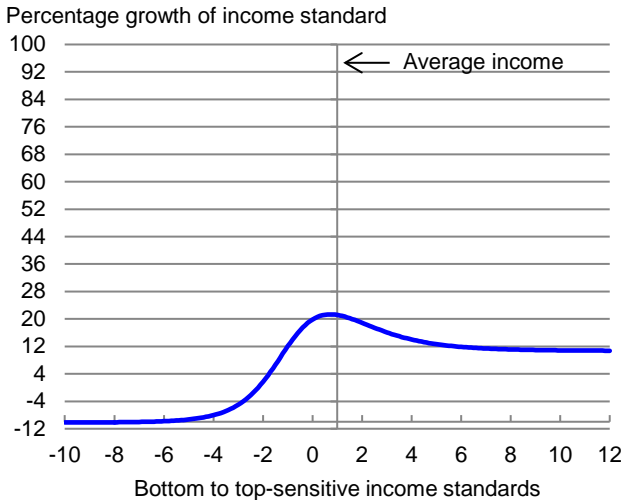

StatLink ज्ञाs http://dx.doi.org/10.1787/888933129885

The figures read as follows. Panel A compares Sweden to Turkey: for a common growth in average income, in Turkey all bottom-sensitive income standards grew much faster than the average, whereas top-sensitive income standards grew more slowly, implying a decline in inequality. In Sweden, the opposite occurred, implying an increase in inequality. Panel C illustrates contrasting inequality developments in the two halves of the distribution: Spain experienced lower growth in top-sensitive income standards compared with the middle of the distribution, implying contracting inequalities in the upper-half of the income distribution, but at the same time slower growth in bottom-sensitive income standards compared with the middle of the distribution, implying increasing inequalities in the middle and lower half of the income distribution. See text for details.

Source: OECD Income Distribution Database.

3. From GDP per capita to household disposable income and its distribution

\subsection{The empirical approach in a nutshell}

Broadening the policy perspective from GDP per capita to household incomes requires establishing the link between these two measures of material living standards. The empirical approach exposed in Box 2 is used first to examine the extent to which GDP per capita has trickled down to household, and then to assess the joint impact of structural reforms on GDP per capita and household incomes, on average and across the distribution. 


\section{Box 2. Overview of the baseline and policy-augmented models}

The baseline model builds on the joint estimation of GDP per capita and household income equations. The GDP per capita specification is based on the augmented-Solow model (Mankiw, Romer and Weil, 1992) and therefore the long-run determinants of GDP are human and physical capital, labour-augmenting efficiency and population growth. The household income specification is based on the assumption that in the long run the level of income is mainly driven by the level of GDP per capita. In addition to the level of GDP per capita, the baseline household disposable income specification includes a proxy for terms-of-trade fluctuations and country-fixed effects. A previous study showed that the contribution of terms-of-trade fluctuations to the gap between real GDP per capita and average household disposable income was particularly large in commodity-exporting countries, and that it could also be significant elsewhere (Causa et al., 2014). The baseline estimation is produced across the full range of top to bottom-sensitive household income standards and covers average income as the benchmark case.

The baseline analysis allows for measuring the household disposable incomes elasticity to GDP per capita for: i) average household income $(\alpha=1)$ and ii) household incomes at different points of the distribution, as measured by top to bottom-sensitive income standards $(\alpha \neq 1)$. The comparison of GDP per capita elasticities across $\alpha$ allows for assessing the distributional effects of GDP per capita growth.

The baseline model is then augmented with structural policies as common determinants of GDP per capita and household incomes across the distribution. The analysis focuses on long-run equilibrium effects, in line with the growth literature on structural reforms. Since GDP per capita is systematically included as a determinant of household incomes, the total effects of structural policies on the latter can be decomposed as follows: i) reform effects on GDP per capita which trickle down to household incomes (indirect effects) and ii) reform effects on household incomes over and above those channeled via GDP (direct or additional effects). By construction, indirect effects follow the effects on GDP per capita while the direct effects on household income can either reinforce or offset the effect through GDP. The summary tables presented in this paper report the effects of structural policies on GDP per capita and the total (or net) effects of structural policies on household incomes, combining direct and indirect effects.

While the baseline specification is estimated for the full-range of bottom to top-sensitive income standards, as governed by the parameter $\alpha$, the range of income standards is narrowed for policy analysis. The policy analysis is performed for average income as well as for a selected range of bottom-sensitive income standards. In practice and with reference to the definition of income standards in Box 1, the analysis is produced for parameter values $\alpha$ $=1$ (mean income), $\alpha=0$ (median income), $\alpha=-3$ (income of the lower-middle class), and $\alpha=-8$ (income of the poor).

In turn, the comparison of total policy effects between average income and different bottom-sensitive income standards such as the median, the lower-middle class and the poor provides an indication of reform effects on income inequality. For example, if a given policy reform has a positive income effect which is stronger for poor households compared with the average, this implies that this policy reform is associated with a reduction in income inequality. The focus on bottom-sensitive income standards implies that this paper emphasises the impact of structural reforms on household incomes in the lower half of the distribution.

The baseline estimations cover all OECD countries over the period from the mid-1980s to late 2000s. See Causa, de Serres and Ruiz (2014) for a formal presentation of the empirical model.

\subsection{Has GDP per capita growth trickled down to household disposable incomes across the distribution?}

In principle, domestic production should for the most part "trickle down" to domestic households, which implies that, absent measurement and methodological considerations, the elasticity of average household disposable income to GDP per capita should be close to one in the long run. Associated distributional patterns depend on the differential effects of GDP per capita growth across income groups. The question is then whether economic growth "lifts all boats", including incomes at the lower end of the distribution. It has been mainly studied in the field of poverty, such as e.g. by Dollar and Kraay (2001, 2013), Timmer (1997) and Ravallion and Chen (1997). 
If the benefits of growth are shared across the economic strata, this increases the attractiveness of purely growth-oriented policies. On the other hand, if economic growth typically leaves the poorer groups behind, there may be trade-offs between growth and inequality and pro-growth policies may have to be tempered by distributional considerations. This question is addressed formally using the baseline model exposed in Box 2.

The baseline elasticities presented in Figure 3 indicate that on average across OECD countries and over the period examined (mid-1980s to the late 2000s), gains in real household disposable income have not matched gains in GDP per capita. In addition, growth has been unequal, as the gap between GDP per capita and household incomes has been wider at the lower end of the income distribution. This is indicated by the profile of the elasticity across the income distribution, which falls from 0.80 for high income to 0.75 around the average and 0.60 for low-income households. This finding is in line with the broad conclusions from previous empirical studies on inequality and in particular OECD (2011b), documenting widespread increases in inequality in OECD countries between the mid-1980s and the late 2000s.

Figure 3. From GDP per capita to household disposable incomes across the distribution, baseline elasticities

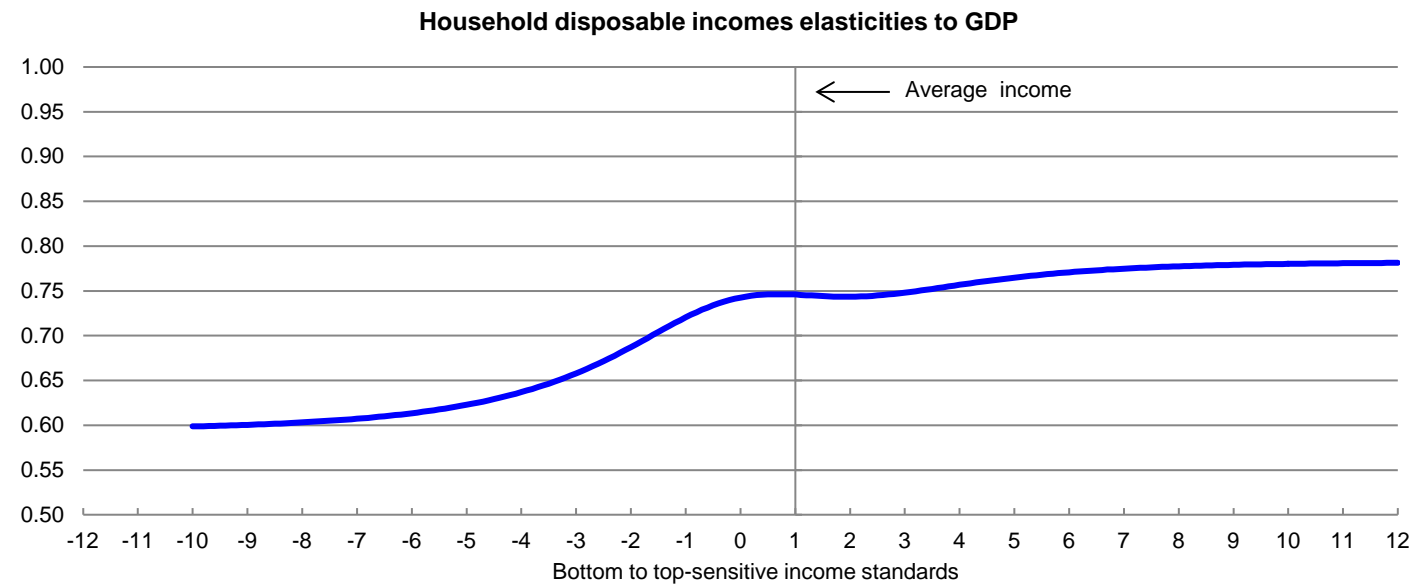

StatLink तills http://dx.doi.org/10.1787/888933129904

Note: Elasticities obtained from the joint estimation of GDP and household incomes equations, without time trend (but with country fixed effects). It is assumed that GDP per capita drives long-run levels of household incomes across the distribution. See Causa, de Serres and Ruiz (2014) for details.

One would expect GDP per capita and average household disposable income to move in parallel, at least over a sufficiently long period. However, a number of factors could explain the relatively low elasticity obtained over the sample examined. First, some of the aforementioned measurement limitations associated with household income survey data of the kind used for this study can account for part of the discrepancy:

- The underestimation of top incomes. Severe under-representation of top-income household could account in part the low elasticity even at the level of average household if this group has benefited from a growing share of total income, as has been documented in several countries (OECD, 2011b).

- The exclusion of capital gains as a source of income. Again, insofar as the share of profits distributed in the form of capital gains has been rising during the period examined, this would result in measured household income growing less rapidly than GDP per capita. 
Second, aside from measurement problems, the low elasticity reported above may also reflect incomes transfers across the main economic sectors, which may have persisted long enough to have created a wedge between GDP per capita and household disposable incomes over a period of 25 years. More specifically, this gap would suggest a rise in income transfers from households to the public sector and the corporate sector: ${ }^{11}$

- A growing share of GDP going to the public sector could explain the lower elasticity at the bottom of the distribution if this has been associated with a partial reversal of redistribution policies. Causa, de Serres and Ruiz (2014) address this issue more formally. While associated results tend to confirm some trend decline in the progressivity of tax and benefits systems - consistent with earlier evidence (OECD, 2011b) - they also clearly suggest that this has played a minor role in explaining the growing gap between GDP per capita and household incomes at the bottom of the distribution.

- A growing share of GDP remaining in the corporate sector could explain the low elasticity reported above to the extent that a growing share of corporate profits is saved, i.e. neither distributed in the form of dividends nor necessarily quickly re-invested to expand productive capacity. There is indeed overwhelming evidence of a trend rise in corporate savings across OECD countries, and this trend has been linked to concomitant widespread declines in the labour share of income (Karabarbounis and Neiman, 2012). In addition, the trend rise in the profit share of GDP per capita would imply that associated income transfers from the corporate to the household sector has increased for shareholders - generally households in the upper-end of the income distribution. This could have contributed to explain the lower elasticity at the bottom of the distribution.

Assessing the relative contribution of these factors to the growing gap between GDP and household income on average over the sample is beyond the scope of this paper. In order to properly identify the effects of policies by reducing measurement but also endogeneity and omitted variable concerns, the policy analysis systematically controls for country-specific time trends.

4. The impact of structural policies on GDP per capita and household incomes across the distribution

The analysis reported in this section focuses on policies and institutions that in the past have been found to boost output growth either directly or indirectly via labour productivity (e.g. multifactor productivity, both at the aggregate level and at the industry-level) and labour utilisation (e.g. participation and unemployment, both at the aggregate level and for population sub-groups). It covers the areas of tax policies, labour market and welfare policies as well as product market regulation. ${ }^{12}$ It then examines the influence of up-skilling. The role of non-policy factors such as technical change along with globalisation is only covered succinctly in the last section. ${ }^{13}$

\subsection{Labour market and welfare policies}

Labour market policy reforms are often designed to boost aggregate employment through work incentives, and via this channel, output growth. At the same time, these policies also affect income inequality through their impact on the earnings distribution. For some reforms, these two impacts on measures of inequality may be offsetting each other (OECD 2013a, Chapter 2). For example, recent evidence suggests that reducing unemployment benefits and lowering statutory minimum relative

11. Part of the income may have gone also to the rest of the world, but since the sample includes nearly all OECD countries, it is likely that net income flows would largely balance overall. In addition the estimates control for those real income transfers which are channelled via changes in terms-of-trade.

12. See Causa, de Serres and Ruiz (2014) for details on the policy data.

13. This topic has been at the core of numerous inequality studies, such as Chapter 2 of OECD (2011b) and has been covered more recently from a trade specialisation perspective (Johansson and Olaberria, 2014). 
to median wages are associated with both higher wage dispersion and higher employment rates (among low-skilled workers), with an unclear net change on inequality among the working-age population (OECD, 2011b and Koske et al, 2012). For other reforms, however, wage and employment effects may reinforce each other, resulting in both stronger growth and smaller inequality. This could be the case of policy reforms aimed at easing the strictness of job protection on regular contracts as a way to tackle labour market duality (i.e. the existence of separate segments where comparable workers enjoy differential wage conditions and job protection). ${ }^{14}$ Results from the empirical analysis are reported in Table 1.

14. See Koske et al. (2012). 
Table 1. The effects of labour market and welfare policies on GDP per capita and household disposable incomes across the distribution

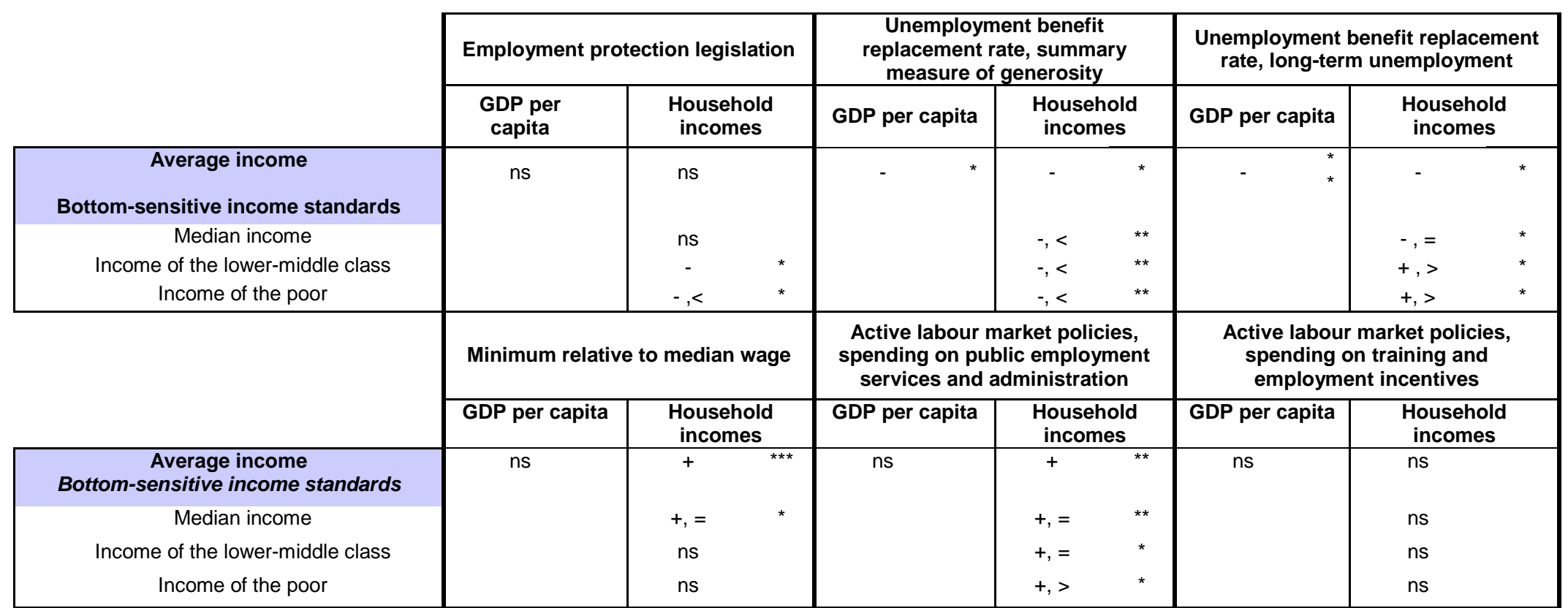

Note: The entries of this table come from the estimation of the simultaneous effects of policies on long-term levels of GDP and household incomes across the distribution. See Causa, de Serres and Ruiz (2014) for details on the definition of policy variables, specification and econometric technique.

The entres can be read as folle table also provides (statistical) comparison of estimated policy effects on household income standards at different is for a are negative for all income groups and they are more negative for median income, incomes of the lower middle class and incomes of the poor, in each case compared with average income. The symbols ( $* \star \star \star \star \star \star)$ denote respectively statistical significance at 10,5 and $1 \% \mathrm{t} \mathrm{level}$ 
Job protection

The effect of stringent job protection on GDP per capita is found to be negative but the estimate falls just short of statistical significance at standard confidence levels. ${ }^{15}$ Earlier studies based on disaggregated data have provided fairly strong evidence that easing job protection legislation in the average OECD country would raise multifactor productivity by enhancing workers' reallocation across firms and industries, even though the associated effects may take time to materialise. ${ }^{16}$

The empirical estimates also fail to identify any effects of job protection on average household income. By contrast, the findings reported in Table 1 point to a negative impact on household incomes of the lower-middle class and, even more, the poor. Although these results are too fragile to support strong conclusions, taken at face value they would indicate potential policy synergies as they imply that reforms easing hiring and firing procedures could serve both efficiency and equity objectives. Earlier studies found that a large and growing gap in the degree of protection between open-ended (permanent) and fixed-term (temporary) contracts tended to be associated with rising income inequality. Such finding is consistent with "insider-outsider" mechanisms and institutional settings associated with labour market duality. ${ }^{17}$ Under such regimes, insiders, generally prime-aged medium-skilled males, enjoy employment security and bargaining power while outsiders, generally youth or the low-skilled, are more likely to be priced out of the labour market and over-represented under atypical contracts with lower pay and low security.

Unemployment benefits

The results reported in Table 1 provide evidence of a negative link between unemployment benefit levels and GDP per capita, suggesting that reductions in benefit generosity have tended to boost output. This finding holds at the level of average household income. But, distributional effects are found to depend on whether the reform affects all unemployed workers or is targeted to the longterm unemployed:

- Untargeted reductions in replacement rates are found to raise household incomes, with an impact that is not much different across the distribution. As a result, such reforms are found to increase household disposable incomes with little effect on income inequality; These results would tend to suggest that in the long-run, employment gains ${ }^{18}$ would largely offset income losses from reduced transfers and increased wage dispersion. But these results need to be taken with caution; average findings across the OECD may not hold at all levels of benefit generosity -reducing unemployment benefits would neither be equitable nor efficient in countries where those benefits are relatively low.

- Reductions in replacement rates targeted to the long-term unemployed (i.e. benefits for jobseekers in the fourth and fifth year of unemployment, which include additional social assistance transfers when those are available) are found to increase disposable incomes for the median household but to reduce disposable incomes for the lower-middle class and, even more, poor households - unambiguously pointing to higher inequality.

The differential distributional implications associated with the two measures of benefit generosity could tentatively reflect that targeting unemployment benefit reforms to the long-term unemployed may deliver relatively less employment gains because the long-term unemployed have usually lower chances to find a job relative to the recently unemployed, reflecting compositional effects as well as skills erosion.

15. The estimated parameter is only significant at $12 \%$ confidence level.

16. See Andrews and Cingano, (2013); Bassanini et al. (2009), Bassanini and Garnero, (2013). In contrast, the reform effects on aggregate employment are rather ambiguous, as lower job protection tends to raise both unemployment inflows and outflows.

17. This result is in line with empirical evidence in Koske et al. (2012) based on decile ratios for full-time employees.

18. For evidence on employment effects see e.g. Nunziata, (2002), Bassanini and Duval (2006), de Serres and Murtin (2013) Nickel et al. (2005), OECD, (2011b). 
Active labour market policies

Reforms of unemployment benefit systems are often formulated in combination with recommendations to strengthen active labour market policies (ALMPs) so as to enhance the efficiency of job-search support, activation and training programmes for the unemployed. However the macro effects of ALMPs are difficult to identify empirically, ${ }^{19}$ because available expenditure-based measures fail to properly capture policy design or effectiveness and are very sensitive to the economic cycle. For the empirical analysis, the latter problem is partly addressed by removing the cyclical component from the policy indicator. Even so, the estimates fail to identify a significant effect on GDP per capita. On the other hand, there is evidence of significant positive effects on average household incomes. This finding holds for household incomes down the distribution and associated income gains are found to be larger for the poor, pointing to equalising effects. This tentatively indicates that steppingup job-search support and programmes for the unemployed can increase jobseekers' employment chances and wages once in employment and, via this channel, reduce income inequality - resulting in policy synergies between the efficiency and equity objectives.

\section{Minimum Wages}

The empirical analysis fails to find significant evidence of an impact of the ratio of minimum-tomedian wages on GDP per capita. ${ }^{20}$ However, the results indicate that reductions in minimum wages tend to lower household mean and median disposable incomes, though not necessarily the income of the poor. This finding is a priori surprising insofar as minimum wages are designed to support incomes of the most vulnerable workers. However, it may reflect a higher proportion of jobless households at the bottom end of the distribution, which are not directly affected by cuts in minimum wages. In fact, lower minimum wages may raise the job prospects of low-skill individuals, improving at the margin the income of these households. In contrast, cuts in minimum wages may have more detrimental income effects on workers whose earnings are closer to the median wage. Minimum wage reductions could also generate broader wage moderation effects spreading up the income distribution. ${ }^{21}$ This would be consistent with the finding of positive and statistically significant effect of minimum wages on mean and median incomes.

$$
\text { Tax policy }
$$

Many tax policies raise well-known trade-offs with respect to growth and equity objectives. ${ }^{22}$ Economic theory and empirical evidence suggests that the tax structure influences macroeconomic efficiency and in particular that direct taxes have relatively more distortionary effects by reducing incentives to work and invest. One of the highest ranked growth-friendly tax reforms, ${ }^{23}$ shifting the tax burden away from income taxes to consumption and property taxes, may in principle have adverse effects on inequality through various channels. For instance, reform-driven positive

19. See Kluve (2010) for a survey on the effectiveness of ALMPs to improve labour market performance. Vanhoult (1997) provides some evidence on inequality-reducing effects from higher spending on ALMPs.

20. Only countries with statutory and universal minimum wages are included in this specification. Other countries also effectively set through collective agreements in a number other countries but these minima can vary substantially across sectors and according to a worker's age, experience and qualifications.

21. The positive effect of declines in minimum wages on wage dispersion is confirmed by a large number of empirical studies (di Nardo et al. 1996; Lee, 1999, Lemieux, 2006 for the US; Koeniger et al. 20007 and Checchi and Garcia-Penalosa, 2010, Koske et al. 2012, for panels of OECD countries). The literature is less conclusive regarding employment: while some studies such as Koske et al. (2012) cannot detect a link between minimum wages and overall employment, others find negative employment effects, at least for some workers such as the very low-skilled (see Neumark and Wascher, 2007 for a review). The few studies that looked at the combined effect (as measured by the Gini index for labour income inequality, see e.g. Checchi and Garcia-Penalosa, 2008) conclude that an increase in minimum wages from their current level would generally raise inequality. This issue however is far from being settled in the literature.

22. $\quad$ Koske et al. (2012), Cournede et al. (2013).

23. See Arnold et al. (2011) and Arnold (2008) for a ranking of tax instruments with respect to their relationship with economic growth. 
employment effects can be counterbalanced by increased income dispersion resulting from lower tax progressivity. Also, empirical evidence derived from the joint analysis of micro-level consumption and income data suggests that consumption taxes can be regressive, at least in the short-run. ${ }^{24}$ There is ambiguity with respect to the distributional effects of property taxes. On the one hand, depending on how they are designed, recurrent taxes on immovable property can be regressive with respect to disposable incomes; on the other, inheritance and capital gains tax clearly reduce wealth inequality. ${ }^{25}$

The empirical framework used in this paper, based on a long-run relationship between household incomes and GDP per capita allows for capturing these longer-term effects of changes in tax policies on the two income measures. However, the analysis deserves a cautious interpretation considering that both the level and structure of taxation are also likely to have a direct and more mechanical influence linked to measurement on the wedge between GDP per capita and household disposable incomes:

- Disposable income is by definition measured net of taxes and transfers. Hence, from a purely static and accounting perspective, changes in taxation that lead to a temporary transfer of income from households to the government (or vice versa) will likely have an impact on measured household disposable income at a given point in time.

- Many forms of taxation are not taken into account in the measurement of real household disposable incomes. This is the case in particular of taxes paid on the consumption of goods and services. In principle, their effects on real disposable income may be captured through changes in consumer prices but this is valid only for the average income and even in this case changes in prices can reflect factors other than taxes. ${ }^{26}$ As a result, changes in the structure of taxation are likely to have a first-round, accounting effect on household disposable income even if the reform keeps the overall level of taxation unchanged.

Bearing these caveats in mind, there is no evidence that shifting the tax burden away from income taxes to consumption and property taxes raises trade-offs between the objectives of achieving higher efficiency, household material living standards and equity (Table 2):

- In line with previous studies, raising tax revenues by relying relatively more on direct (i.e. personal and corporate income) taxes is found to depress GDP per capita. It is also found to have a negative effect on average household income as well as on lower incomes, without any significant differences on the magnitude of the impact across the distribution. However, the negative effect of direct taxes is estimated to be of a lower magnitude in the case of household incomes compared with GDP per capita. The decomposition of direct taxes between the personal and corporate tax components indicates that their combined negative impact is driven by the personal income tax component.

- Consistent with the former result and previous studies, raising tax revenues by relying relatively more on consumption and property taxes is found to boost GDP per capita. However, no significant effect on average household income is found. The estimated neutral real household income effects from consumption and property taxes holds for median income and income of the lower-middle class, but there is some evidence of positive effects on income of the poor, possibly reflecting lower tax wedges and unemployment.

The potential adverse impact of labour taxation on income can also be assessed by looking at the effect of marginal labour tax wedges faced by a representative average wage worker, for each

24. See inter alia, Ruiz and Trannoy (2008), for a microsimulation study on the short-term (that is immediate) distributional effects of consumption taxes in France. The paper runs against the prior that consumption taxes are strongly regressive. Indeed, the main conclusion of the micro-based analysis is that that the design of indirect taxes can only marginally address the redistribution objective, reflecting the relatively homogeneity of consumption profiles across incomes deciles.

25. See Koske et al. (2012).

26. The unavailability of price indices by income groups deny the possibility to identify distributional effects. 
OECD country and each year. ${ }^{27}$ Holding average labour tax wedges and tax revenues constant, higher marginal tax wedges are found to be associated with lower GDP per capita and average household disposable income. The similar magnitude of the estimated effect across the different income levels precludes drawing any inequality implications. ${ }^{28}$ The findings of a negative effect from high marginal taxes on income are in line with theory and empirical evidence, which point to a relatively high responsiveness of labour force participation or hours worked to net labour income among specific workforce groups such as the low-skilled and women but also top wage-earners. ${ }^{29}$ Since the policy indicators used in the analysis include employers' social security contributions, the estimates could also reflect labour demand effects.

27. The analysis relies on statutory rates derived from OECD Taxing wages models. Average tax wedges are defined as the difference between total labour compensation paid by the employer and the net takehome pay of employees, as a ratio of total labour compensation. The marginal tax wedge is defined as the difference between the change in total labour compensation paid by employers and the change in the net take-home pay of employees, as a result of an extra unit of national currency of labour income. The difference is expressed as a percentage of the change in total labour compensation. The data refer to a single individual without children at $100 \%$ of average earnings. See Causa, de Serres and Ruiz (2014) on data details.

28. The median income estimate is lower than, but close to, statistical significance (at $13 \%$ confidence level).

29. Empirical evidence on the detrimental effects of labour taxes on labour utilisation is abundant. See Causa (2009) for a short survey. 
STRUCTURAL REFORMS AND INCOME DISTRIBUTION

Table 2. The effects of tax policy on GDP per capita and household disposable incomes across the distribution ${ }^{1}$

\begin{tabular}{|c|c|c|c|c|c|c|c|c|c|c|c|}
\hline & \multicolumn{2}{|c|}{ Share of direct taxes } & \multicolumn{2}{|c|}{ Share of personal income tax } & \multicolumn{2}{|c|}{ Share of corporate income tax } & \multicolumn{2}{|c|}{$\begin{array}{l}\text { Share of consumption and property } \\
\text { taxes }\end{array}$} & \multicolumn{3}{|c|}{ Labour tax wedge, marginal (2) } \\
\hline & $\begin{array}{l}\text { GDP per } \\
\text { capita }\end{array}$ & $\begin{array}{l}\text { Household } \\
\text { incomes }\end{array}$ & $\begin{array}{l}\text { GDP per } \\
\text { capita }\end{array}$ & $\begin{array}{l}\text { Household } \\
\text { incomes }\end{array}$ & $\begin{array}{l}\text { GDP per } \\
\text { capita }\end{array}$ & $\begin{array}{l}\text { Household } \\
\text { incomes }\end{array}$ & $\begin{array}{l}\text { GDP per } \\
\text { capita }\end{array}$ & $\begin{array}{l}\text { Household } \\
\text { incomes }\end{array}$ & GDP per capita & $\begin{array}{l}\text { Household } \\
\text { incomes }\end{array}$ & \\
\hline \begin{tabular}{|l} 
Average income \\
Bottom-sensitive income standards
\end{tabular} & $\star * \star \star$ & & $\star \star \star$ & 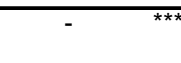 & ns & + & *** & ns & - & - & ** \\
\hline $\begin{array}{l}\text { Median income } \\
\text { Income of the lower middle class }\end{array}$ & & $\begin{array}{l}-,< \\
-,=\quad * \star \\
-,\end{array}$ & & $\begin{array}{ll}-,= & \star \star \star \\
-,= & \star \star \star\end{array}$ & & $\begin{array}{c}+,> \\
\text { ns }\end{array}$ & & $\begin{array}{l}\text { ns } \\
\text { ns }\end{array}$ & & $\begin{array}{l}\text { ns } \\
-,=\end{array}$ & ** \\
\hline Income of the poor & &,$-=$ & &,$-=$ & & ns & & + & &,$-=$ & ** \\
\hline
\end{tabular}

Note: The entries of this table come from the estimation of the simultaneous effects of policies on long-term levels of GDP and household incomes across the distribution. See

Causa, de Serres and Ruiz (2014) for details on the definition of policy variables, specification and econometric technique.

The entries can be read as follows. + denotes a positive policy impact while - denotes a negative one. The table also provides (statistical) comparison of estimated policy effects on household

income standards at different points of the distribution, respectively the median, the lower-middle class and the poor, with policy effects on average household income. Hence, the cases $>,<$ and

denote, respectively, a positive impact of the reform which is, for a given income group, statistically higher, lower, or equal than that on average income. For example, in the case of direct taxes,

household income effects are negative for all income groups and they are higher in absolute value for median income, while they are statistically equivalent for incomes of the lower-middle class and incomes of the poor, in each case compared with average income. The symbols $\left({ }^{*},{ }^{* *},{ }^{* \star *}\right)$ denote respectively statistical significance at 10,5 and $1 \%$ level.

1. All the regressions control for tax revenue as a share of GDP.

2. This regression controls for the average tax wedge. See text for definitions of average and marginal tax wedges. 


\subsection{Product market regulation}

Previous analysis has found that relaxing anti-competitive product market regulation can bring productivity and employment gains in the long run, therefore spurring economic growth (Bourlès et al., 2010; Conway et al., 2006). However, the impact on income inequality is uncertain and empirical evidence generally inconclusive (OECD, 2013a; Guadalupe, 2007; Koske et al., 2012). This is because employment gains ${ }^{30}$ may be at least partly offset by changes in the wage dispersion, as more intense product market competition tends to reduce the bargaining power of workers. The analysis relies on the OECD's summary index of product market regulation in seven non-manufacturing industries, covering energy, telecom and transport sectors. ${ }^{31}$

As shown on Table 3, no statistically significant impact of product market regulation on long-run GDP per capita could be identified. This runs against priors and previous evidence and aside from data limitations could reflect the difficulty to identify the effects of regulation at the aggregate level as opposed to the industry or firm levels. By contrast, there is evidence of negative effects from stringent product market regulation on average household disposable income. Such negative effects hold across the income distribution - and increasingly so for households at the lower end, pointing to disequalising effects. This finding could reflect that potential declines in wage dispersion could be more than offset by adverse employment and price effects. This suggests that reducing overall regulatory barriers to product market competition would tend to boost household incomes and reduce income inequality, pointing to potential policy synergies between efficiency and equity objectives.

Table 3. The effects of product market regulation on GDP per capita and household disposable incomes across the distribution

\begin{tabular}{|c|c|c|c|}
\hline & \multicolumn{3}{|c|}{ Product market regulation } \\
\hline & GDP & $\begin{array}{c}\text { Household } \\
\text { incomes }\end{array}$ & \\
\hline $\begin{array}{l}\text { Average income } \\
\text { Bottom-sensitive income standards }\end{array}$ & ns & & \\
\hline $\begin{array}{l}\text { Median income } \\
\text { Income of the lower middle class } \\
\text { Income of the poor }\end{array}$ & & $\begin{array}{l}-,< \\
-,< \\
-,<\end{array}$ & 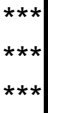 \\
\hline
\end{tabular}

Note: The entries of this table come from the estimation of the simultaneous effects of policies on long-term levels of GDP and household incomes across the distribution. See Causa, de Serres and Ruiz (2014) for details on the definition of policy variables, specification and econometric technique.

The entries can be read as follows. + denotes a positive policy impact while - denotes a negative one. The table also provides (statistical) comparison of estimated policy effects on household income standards at different points of the distribution, respectively the median, the lower-middle class and the poor, with policy effects on average household income. Hence, the cases >, < and = denote, respectively, a positive impact of the reform which is, for a given income group, statistically higher, lower, or equal than that on average income. In the case of product market regulation, household income effects are negative for all income groups and they are higher in absolute value for median income, incomes of the lower-middle class and incomes of the poor, in each case compared with average income. The symbols $\left({ }^{*},{ }^{* *},{ }^{\star \star *}\right)$ denote respectively statistical significance at 10,5 and $1 \%$ level.

30. Bassanini and Duval (2006); Griffith et al. (2007); Nicoletti and Scarpetta, (2005); Fiori et al. (2007); Nicoletti et al. (2001).

31. This is the only policy index available on a time-series basis but is clearly quite narrow and as result is not the best proxy for measuring the overall effects of anti-competitive product market regulation on either GDP per capita or household income. This implies that associated results are not always comparable with previous work, for instance those that used other indices of product market regulation and/or alternative identification strategies. 
Rapid technological progress and growing cross-border trade flows have been important drivers of growth, but they have also been seen as potential culprits for growing inequalities of earnings, particular through their impact on the skills composition of jobs. The potential impact of these factors as well as of education is examined in this sub-section.

Up-skilling

While the positive link between human capital, employment and GDP per capita is well established, the relationship between education and income inequality is notoriously ambiguous. Moving to a better-educated workforce can have two separate effects (Knight and Sabot, 1983): i) a composition effect, whereby a rise in the share of highly-educated (high-wage) workers raises earnings inequality, at least initially; and ii) a rate-of-return effect, whereby a rise in the share of highly-educated workers reduces the returns to education; as a result of these contrasting forces, the combined effect on inequality is unclear a priori.

The household income equation is simply augmented with education, where the latter is measured by mean years of schooling (Table 4). As expected, up-skilling is found to boost long-term levels of GDP per capita and average household income. Household incomes effects are also positive across the distribution, and with the same order of estimated magnitude, which suggests the absence of distributional implications. The decomposition of total household income effects indicates that beyond positive effects channelled via GDP, there are no additional benefits from education at the household level (see details in Causa, de Serres and Ruiz, 2014).

These findings imply that rising education did not boost household incomes as much as GDP per capita. They could reflect decreasing returns to education at the OECD-wide level, due to the relatively high development stage of the average OECD country - available schooling indicators probably no longer adequately measure population skills and the quality of education. Even though the analysis could not rely on policy indicators but only on performance indicators, these results would still indirectly suggest that reforms aimed at encouraging educational up-skilling, while promoting equity in access to education, can serve both growth and equity objectives. 
Table 4. The effects of up-skilling on GDP per capita and household disposable incomes across the distribution

\begin{tabular}{|c|c|c|c|}
\hline & \multicolumn{3}{|c|}{ Mean years of schooling } \\
\hline & GDP & $\begin{array}{l}\text { Household } \\
\text { incomes }\end{array}$ & \\
\hline $\begin{array}{l}\text { Average income } \\
\text { Bottom-sensitive income standards }\end{array}$ & 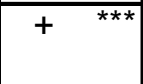 & & \\
\hline $\begin{array}{l}\text { Median income } \\
\text { Income of the lower middle class } \\
\text { Income of the poor }\end{array}$ & & $\begin{array}{l}+,= \\
+,= \\
+,=\end{array}$ & $\begin{array}{l}* \star * \\
\star \star \star \\
\star \star *\end{array}$ \\
\hline
\end{tabular}

Note: The entries of this table come from the estimation of the simultaneous effects of policies on long-term levels of GDP and household incomes across the distribution. See Causa, de Serres and Ruiz (2014) for details on the definition of policy variables, specification and econometric technique.

The entries can be read as follows. + denotes a positive policy impact while - denotes a negative one. The table also provides (statistical) comparison of estimated policy effects on household income standards at different points of the distribution, respectively the median, the lowermiddle class and the poor, with policy effects on average household income. Hence, the cases $\rangle$, $<$ and $=$ denote, respectively, a positive impact of the reform which is, for a given income group, statistically higher, lower, or equal than that on average income. In the case of mean years of schooling, total household income effects are positive for all income groups and they are of equal size for median income, incomes of the lowermiddle class and incomes of the poor, in each case compared with average income. The symbols $\left({ }^{*},{ }^{\star *},{ }^{\star \star}\right)$ denote respectively statistical significance at 10, 5 and $1 \%$ level.

Technological progress and globalisation

There is some consensus, in both developed and, to a lesser extent, developing countries, that globalisation is a growth-enhancing force, but no consensus, and mixed empirical evidence, about the distributional implications. Economic globalisation involves increased exposure to international trade and financial movements, increased mobility of production factors (i.e. workers and capital) and increased fragmentation of the production process. The effects of globalisation on overall income inequality have mainly focused on the earnings dispersion channel as opposed to the employment channel. Available evidence would seem to suggest that globalisation-induced inequality effects are mainly driven by greater wage dispersion, in particular arising from changes in the skill and industry composition of labour demand. ${ }^{32}$

For advanced economies, the distributional impacts of globalisation would come through a variety of channels such as: i) increased wage dispersion resulting from import competition from low-wage developing countries, ii) growing outward investment reflecting the rapid development of international production-sharing (from home companies to their foreign affiliates) distorting the wage distribution of home countries by shifting relative demand within industries - the so called "outsourcing hypothesis" (Feenstra and Hanson, 2003; Hijzen, 2007), iii) price reductions in goods that are disproportionately consumed by low-income households; iv) lower wage differentials resulting from increased demand for unskilled labour due to inward foreign investment in low-skill sectors in particular services (i.e. hotels and retail distribution) and; $v$ ) employment creation resulting from e.g. greenfield investment or innovation- induced increase in consumption.

The first two factors would tend to be less favourable to incomes at the lower end of the distribution, whereas the last three would in contrast be expected to benefit more low-income wageearners and households. To shed light on these effects, the analysis is selectively extended to cover some broad areas which have been found to influence inequality in previous OECD work (Chapter 2 of OECD, 2011b) - and accordingly this is done by controlling for concomitant structural shifts affecting the composition of OECD economies, e.g. in terms of the sectoral (agriculture, industry and services) and the share of women in total employment. Main results are presented in Table 5.

Stronger export intensity is found to boost long-run GDP per capita and average household disposable income. Such effects hold across the distribution of household income, with stronger estimated gains for the poor - implying reduced inequality. The income-equalising effects of export intensity are broadly consistent with previous empirical literature (e.g. Jaumotte et al., 2008 and Koske 
et al., 2012) pointing to the positive effects of international competition on GDP and employment. Overall, these findings signal synergies across policy objectives, i.e. that reforms aimed at encouraging exports among domestic firms could boost efficiency and equity.

The analysis delivers mixed findings on the impact of international financial integration: ${ }^{33}$

- The influence of inward FDI is qualitatively close to that of export intensity - a likely reflection of the interplay between trade and FDI and the resulting difficulty to properly identify their sole effects: there is evidence of positive effects on GDP per capita and positive equalising effects on household disposable incomes. This finding could reflect FDI-induced demand for unskilled labour and associated employment creation; and it would suggest that policy reforms aimed at easing barriers to entry for foreign firms could serve both the efficiency and equity objectives.

- The impact of outward FDI is significant on neither GDP per capita nor average household income. By contrast, there is some evidence of negative effects on household incomes of the lower-middle class and the poor. These effects are consistent with the outsourcing hypothesis but could more broadly signal that jobs created and wages distributed by multinational companies do not mostly accrue to domestic but to foreign households.

Globalisation may also affect income distribution insofar as increased trade and international capital flows facilitates the diffusion of technology, increasing thereby wage dispersion via mechanisms such as skill-biased technological change. ${ }^{34}$ To the extent that skill-biased technological change shifts demand of labour towards higher skills and especially when this increase in demand is not matched by a sufficient increase in the supply of skilled workers, technical progress may increase wage inequality. The implications of this hypothesis for inequality have found empirical support for many OECD countries (Autor et al., 2006, Goos et al., 2009 and Braconnier and Ruiz-Valenzuela, 2014). Going further, recent evidence strongly suggests that skill-biased trade specialisation is associated with higher wage inequality, even accounting for technological change (Johansson and Olaberria, 2014).

Technological progress, as measured by the share of investment in communication technology (ICT) in overall investment, is found to boost long-run GDP per capita and average household disposable incomes. Average household income gains hold across the distribution and are of the same estimated order of magnitude. As a result, there is no evidence of inequality effects, contrary to priors. This could reflect methodological differences with empirical studies that have highlighted a significant technology-driven disequalising impact: in previous studies, such effect has been estimated on the basis of wage dispersion among employed individuals. ${ }^{35}$ Furthermore, such effects have generally been estimated on the basis of technological progress being proxied by linear time trends; the failure to identify a specific dis-equalising effect from ICT could in this context be due to the inclusion of time trends in the household equations.

33. Financial integration is measured by de facto indicators, based on the following arguments: i) de jure legal restrictions on FDI transactions may not adequately reflect actual exposure of countries to international capital markets and in particular does not distinguish between inward and outward financial transactions; ii) the OECD indicator of legal barriers to FDI is available for a few years only, making it impossible to use it in a time-series context. One important shortcoming associated with de facto measures is the higher risk of endogeneity bias compared with de jure measures, implying the need to interpreted associated results with caution.

34. Thoenig and Verdier (2003), Stojanovska and Cuyvers (2010), Bloom et al. (2008).

35. Braconier and Ruiz-Valenzuela (2014), OECD (2011b), Koske et al. (2012) Johansson and Olaberria (2014). But, Koske et al (2012) could not identify any effect of innovation when moving from the concept of labour inequality to overall inequality (measured by the Gini coefficient based on disposable incomes for the whole population). This result is more comparable with the present study than that based on wage dispersion. 
Table 5. The effects of up-skilling, technological progress and globalisation on GDP per capita and household disposable incomes across the distribution

\begin{tabular}{|c|c|c|c|c|c|c|c|c|c|c|c|c|c|c|}
\hline & \multicolumn{2}{|c|}{ Export intensity } & \multicolumn{2}{|c|}{ Import penetration } & \multicolumn{2}{|c|}{ FDI inflow } & \multicolumn{2}{|c|}{ FDI outflow } & \multicolumn{3}{|c|}{ ICT investment share } & \multicolumn{3}{|c|}{ Mean years of schooling } \\
\hline & GDP & $\begin{array}{l}\text { Household } \\
\text { incomes }\end{array}$ & GDP & $\begin{array}{c}\text { Household } \\
\text { incomes }\end{array}$ & GDP & $\begin{array}{c}\text { Household } \\
\text { incomes }\end{array}$ & GDP & $\begin{array}{c}\text { Household } \\
\text { incomes }\end{array}$ & GDP & $\begin{array}{c}\text { Household } \\
\text { incomes }\end{array}$ & & GDP & $\begin{array}{c}\text { Household } \\
\text { incomes }\end{array}$ & \\
\hline \begin{tabular}{|l} 
Average income \\
Bottom-sensitive income standards
\end{tabular} & $+* \star$ & + & $-\quad *$ & ns & $+\star \star * \star \mid$ & + & ns & ns & 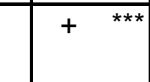 & & *** & 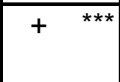 & + & 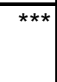 \\
\hline $\begin{array}{l}\text { Median income } \\
\text { Income of the lower middle class }\end{array}$ & & $\begin{array}{l}+,= \\
+,=\end{array}$ & & $\begin{array}{l}n s \\
n s\end{array}$ & & $\begin{array}{l}+,= \\
+>\end{array}$ & & ns & * & $\begin{array}{l}+,= \\
+=\end{array}$ & $\begin{array}{c}\star \star \star \\
\star \star \star\end{array}$ & & $\begin{array}{l}+,= \\
+=\end{array}$ & $\begin{array}{l}\star \star \star \\
\star \star \star \star\end{array}$ \\
\hline Income of the poor & & $+>$ & & $n s$ & & $+>$ & & $-=$ & * & $+=$ & $\star \star \star \star$ & & $+=$ & $\star \star \star *$ \\
\hline
\end{tabular}

Note: The entries of this table come from the estimation of the simultaneous effects of policies on long-term levels of GDP and household incomes across the distribution. See Causa, de Serres and Ruiz (2014) for details on the definition of policy variables, specification and econometric technique.

The entries can be read as follows. + denotes a positive policy impact while - denotes a negative one. The table also provides (statistical) comparison of estimated policy effects on household income standards at different points of the distribution, respectively the median, the lower-middle class and the poor, with policy effects on average household income. Hence, the cases $>$, $<$ and $=$ denote, respectively, a positive impact of the reform which is, for a given income group, statistically higher, lower, or equal than that on average income. For example, in the case of export intensity, total household income effects are positive for all income groups and they are of equal size for median income and incomes of the lower-middle class compared with average income while they are higher for incomes of the poor compared with average income. The symbols $\left(^{*}, * * * *\right)$ denote respectively statistical significance at 10,5 and $1 \%$ level. 
5. Which growth-enhancing policies have the potential to "lift all boats"? A Wrap-up and some illustrative simulations

The empirical analysis shows that a number of structural policies can boost long-term levels of GDP per capita and, via this channel, household disposable incomes. In general, there is limited evidence that growth-enhancing structural policies may raise inequality of disposable incomes in the long term, while a number of them are found to potentially reduce it, tentatively pointing to synergies between the growth and equity objectives.

As a tentative illustration of the quantitative impact of policies, the empirical results are used with a view to compare reforms in terms of their respective effects on different objectives such as efficiency and equity (Table 6). This illustration is produced by taking the estimates at face value and as a result it clearly implies a cautions interpretation. The exercise proceeds as follows:

- $\quad$ GDP per capita estimates are used to standardise policy reforms so that they all deliver a $1 \%$ long-term increase in GDP per capita. The table presents the required change in associated policy parameters.

- Household income estimates are used to simulate the effects of such standardised policy reforms on household disposable incomes, both on the average level and across the distribution.

- In the cases where policies have no significant effects on GDP per capita, the corresponding reforms are standardised so that they deliver a 1\% long-term increase in average household income. Household income estimates are used to simulate the effects of such standardised policy reforms on incomes across the distribution.

This exercise delivers the following main conclusions:

- The long-term gains in average household income from reforms are generally close to those in GDP per capita. This reflects the fact that GDP per capita is a key driver of average household disposable income in the long term.

- Nonetheless, a number of reforms have a differential impact on household income and GDP per capita - especially those at the lower end of the distribution. These are cases where policies are found to have a significant effect over and above the impact via GDP:

- Reducing barriers to competition, reducing unemployment benefits across the board and lowering labour taxation are found to lift incomes of the lower-middle class by more than GDP per capita.

- Shifting from income taxation to property and consumption taxes, boosting ICT investment and tightening unemployment benefits for the long-term unemployed are found to lift incomes of the lower-middle class by less than GDP per capita - the latter reform is even found to reduce disposable incomes of the lower-middle class.

- The results reported in Table 6 point to several cases of long-term policy synergies between the growth and equity objectives. Many structural reforms are indeed found to deliver stronger income gains for households at the lower end of the distribution compared with the average household and can thus be viewed as helping to narrow inequality in disposable incomes. This is the case of reducing regulatory barriers to domestic competition, trade and FDI, stepping-up job-search support and activation programmes and tightening unemployment benefits for all categories of jobseekers. 
Table 6. Wrapping-up: policy reforms to lift GDP per capita and household incomes, on average and across the distribution

\begin{tabular}{|c|c|c|c|c|c|c|}
\hline & & $\begin{array}{l}\text { Effects on } \\
\text { long-term }\end{array}$ & $\begin{array}{l}\text { Effects on long- } \\
\text { term average }\end{array}$ & Effects on IC & $\begin{array}{l}\text { ng-term housel } \\
\text { the distributi }\end{array}$ & ncomes across \\
\hline Example of specific structural policy reform & Change in policy parameters to deliver a $1 \%$ long-term increase in GDP per capita & & & The median & $\begin{array}{l}\text { The lower- } \\
\text { middle class }\end{array}$ & The poor \\
\hline Relax hiring and firing procedures / Reduce labour market duality & $\begin{array}{l}\text { Reduction in the employment protection legistation index approximately equivalent to the stringency of regulation } \\
\text { prevaliling currently in Finland compared with Estonia }\left({ }^{*}\right)\end{array}$ & $1.0\left(^{*}\right)$ & & & 1.4 & 1.9 \\
\hline Reduce the level or duration of unemployment benefits & Untargeted reductions in benefit replacement rates by 3 percentage points & 1.0 & 1.3 & 1.5 & 1.5 & 1.5 \\
\hline Reduce the level of unemployment benefits for the long-term unemployed & Reductions in benefit replacement rates targeted to the long-term unemployed by 4 percentage points & 1.0 & 0.8 & 0.8 & -1.5 & -2.4 \\
\hline $\begin{array}{l}\text { Reform the tax structure by reducing the share of direct (corporate and income) taxes } \\
\text { and inineasisg the share of property or indiriect taxes }\end{array}$ & Reductions in the share of personal income taxes in tax revenue by 1.3 percentage points & 1.0 & 0.5 & 0.5 & 0.5 & 0.5 \\
\hline Reduce marginal tax rates on labour & Reductions in average statutory marginal tax wedges on labour by 3.5 percentage points & 1.0 & 1.3 & $1.3\left({ }^{*}\right)$ & 1.3 & 1.3 \\
\hline Encourage educational upskilling and equity in access to education & General increases in average years of schooling by 0.25 years & 1.0 & 0.9 & 0.9 & 0.9 & 0.9 \\
\hline Reduce barriers to entry for foreign firms -- FDl inflows & Increases in the stock of inward FDl as a share of GDP by 4 percentage points & 1.0 & 1.0 & 1.0 & 1.3 & 1.3 \\
\hline Reduce barriers to exports / Encourage exports among domestic firms & Increases in export intensity by 3 percentage points & 1.0 & 1.1 & 1.1 & 1.1 & 1.2 \\
\hline Encourage innovation and raise the effectivenness of R\&D support & Increases in the share of ICT in overall investment by 4 percentage points & 1.0 & 0.7 & 0.7 & 0.7 & 0.7 \\
\hline & & $\begin{array}{l}\text { Effects on } \\
\text { long-term }\end{array}$ & $\begin{array}{l}\text { Effects on long- } \\
\text { term average }\end{array}$ & Effects on lc & $\begin{array}{l}\text { ing-term house } \\
\text { the distribs }\end{array}$ & incomes across \\
\hline Example of specific structural policy reform & Change in policy parameters to deliver a $1 \%$ long-term increase in average household disposable income & $\begin{array}{l}\text { Gepper } \\
\text { capita }\end{array}$ & 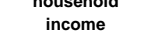 & The median & $\begin{array}{l}\text { The lower- } \\
\text { middle class }\end{array}$ & The poor \\
\hline Step-up job-search support and activation programs for the unemployed & $\begin{array}{l}\text { Increases in spending on adminisistration and PES per unemployed on GDP per capita approximately equivalent to } \\
\text { the current spending gap of reland relative to the Netherlands }\end{array}$ & & 1.0 & 1.0 & 1.0 & 1.3 \\
\hline Increase the minimum cost of labour & Increases in the ratio of minimum relative to median wage by 8.3 percentage points & & 1.0 & 1.0 & & \\
\hline $\begin{array}{l}\text { Relax product market regulation (by easing entry restrictions in non-manufacturing } \\
\text { sectors, reducing barriers to firm entry) }\end{array}$ & 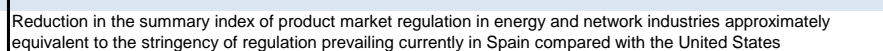 & & 1.0 & 1.4 & 1.8 & 2.9 \\
\hline
\end{tabular}

Note: The table only reports results for which estimated effects are statistically significant. Empty cells refer to estimates which are not statistically significant. See text for details

${ }^{*}$ ) These simulations are produced because the corresponding coefficients are below but very close to statistical significance (at a level of confidence of $12 \%$ for the GDP per capita effect of employment protection and $13 \%$ for the median income effect of marginal tax wedges 
- Conversely, few instances of long-term policy trade-offs between the growth and equity objectives emerged from the analysis. One notable case is a tightening of unemployment benefits for the long-term unemployed as it is found to lift GDP per capita and average household incomes but also to reduce disposable incomes at the lower end of the distribution, a clear indication that it may raise inequality. Reducing minimum relative to median wages could also raise concerns as it is found to depress disposable incomes on average and for the median household, though not for households at the lower end of the distribution.

- In general, the magnitude of the reforms required to lift GDP per capita and household incomes by around 1\% does not seem out of reach. In a number of cases, such as in the area of taxation, unemployment benefits and product markets, the policy changes are of low magnitude compared with past experiences, as observed on average across OECD reforming countries between 1995 and 2005.

6.

\section{Concluding remarks}

The empirical analysis developed in this paper shows that in the long-run, structural reforms can boost both GDP per capita and household disposable incomes, both on average and across the distribution. In addition, there is little evidence of policy trade-offs between efficiency and equity, and even relatively frequent occurrences of policy synergies. These results may reduce concerns associated with potential negative reform effects on household material living standards and inequality. However, further work is needed to deliver a more comprehensive and conclusive assessment. In particular, short-run effects may deviate from long-run equilibrium effects identified in this paper, which calls for assessing the dynamic effects of reforms on household disposable incomes and income inequality. ${ }^{37}$ In the short-run, some reforms are likely to increase income inequality even if this would vanish or even revert in the long-run. Associated welfare implications may need to be taken into account in the reform process.

36. Such tentative scenarios are derived mechanically but are not inconsistent with country-specific reform experiences identified in Bouis et al. (2012) by means of a formal definition of "reform shocks".

37. See Bouis et al. (2012) for an empirical assessment the dynamic effects of structural reforms on economic growth. 


\section{REFERENCES}

Alesina, A. and D. Rodrik (1994), "Distributive politics and economic growth", The Quarterly Journal of Economics, Vol. 109, pp. 465-490.

Alesina, A. and R. Perotti (1996), "Income distribution, political instability and investment", European Economic Review, Vol. 40, pp. 1203-1228.

Arnold, J. (2008), "Do tax structures affect economic growth? Empirical evidence from a panel of OECD countries", OECD Economics Department Working papers No. 463, OECD publishing, Paris.

Arnold, J., B. Bys, C. Heady, A. Johansson, C. Schwellnus and L. Vartia (2011), "Tax policy for economic recovery and growth", The Economic Journal, Bol. 121, issue 550, pp. F59-F80.

Atkinson, A. (1970), "On the measurement of inequality”, Journal of Economic Theory, Vol. 2, No. 3, pp. $244-263$.

Atkinson, A., T. Piketty and E. Saez, (2011) "Top incomes in the long run of history", Journal of Economic Literature, American Economic Association, Vol. 49(1), pp. 3-71, March.

Autor, D., L.F. Katz and M.S. Kearney (2006), "the polarization of the US labor market", AEA Papers and Proceedings, Vol. 96, No. 2, pp. 189-194, May.

Bassanini, A. and R. Duval (2006), "Employment patterns in OECD countries: reassessing the role of policies and institutions", OECD Economics Department Working Papers No. 486, OECD Publishing, Paris.

Bassanini, A. and A. Garnero ( 2013). "Dismissal protection and worker flows in OECD countries: Evidence from cross-country/cross-industry data", Labour Economics, Elsevier, Vol. 21(C), pp, 25-41.

Bassanini, A. and P. Marianna (2009), "Looking inside the perpetual-motion machine: job and worker flows in OECD Countries", IZA Discussion Papers 4452, Institute for the Study of Labor (IZA).

Bassanini, A., L. Nunziata and D. Venn (2009), "Job protection legislation and productivity growth in OECD countries," Economic Policy, CEPR \& CES \& MSH, Vol. 24, pp. 349-402, 04.

Bassanini, A., S. Scarpetta and P. Hemmings (2001),"Economic growth: The role of policies and institutions:panel data. Evidence from OECD Countries", OECD Economics Department Working Papers, No. 283, OECD Publishing, Paris.

Birdsall, N., D. Ross and R. Sabot (1995), "Inequality and growth reconsidered: Lessons from East Asia", World Bank Economic Review, Vol. 9, pp. 477-508.

Bloom, N., M. Draca and J. Van Reenen (2008), "Trade induced technical change? The impact of Chinese imports on innovation, diffusion and productivity," AEA Annual Meeting Paper.

Boarini, R., A. Johansson and M. Mira d'Ercole (2006), "Alternative measures of wellbeing", OECD Social, Employment and Migration working Papers, OECD Publishing, Paris.

Boeri, T. (2010), "Institutional reforms in european labor markets", Università Bocconi e Fondazione Rodolfo Debenedetti.

Boulhol, H., A. de Serres and M. Molnar (2008), "The contribution of economic geography to GDP per capita", OECD Journal: Economic Studies, Vol. 2008/1, OECD Publishing, Paris.

Bouis, R., O. Causa, L. Demmou and R. Duval (2012), "The short-term effects from structural reforms", OECD Economics Department Working Papers No. 949, OECD Publishing, Paris.

Bourguignon, F. and A. Spadaro (2006), "Microsimulation as a tool for evaluating redistribution policies", Journal of Economic Inequality", Vol. 4, pp. 77-106, OECD Publishing, Paris. 
Bourlès, R., G. Cette, J. Lopez, J. Mairesse and G. Nicoletti (2010), "Do product market regulations in upstream sectors curb productivity growth?: Panel data evidence for OECD countries", OECD Economics Department Working Papers, No. 791, OECD Publishing, Paris.

Braconier, H., G. Nicoletti and B. Westmore (2014), "Policy challenges for the next 50 years", OECD Economic Policy Paper, No. 9, July, OECD Publishing, Paris.

Braconier, H., J. Ruiz-Valenzuela (2014), "Gross earnings inequalities in OECD countries and major nonmembers economies: Determinants and future scenarios", OECD Economics Department Working Papers, No. 1139, July, OECD Publishing, Paris.

Causa, O. (2009), "The policy determinants of hours worked across OECD countries", OECD Journal: Economic Studies, Vol. 2009, OECD Publishing, Paris.

Causa, O. and A. Johansson (2009), "Intergenerational social mobility in OECD countries", OECD Journal: Economic Studies, Vol. 2010, pp. 1-44, OECD Publishing, Paris.

Checchi, D. and C. Garcia-Peñalosa (2008), "Labour market institutions and income inequality", Economic Policy, Vol. 23, Issue 56, pp. 601-649,

Checchi, D. and C. Garcia-Peñalosa (2010), "Labour market institutions and the personal distribution of income in the OECD", Economica, Vol. 77, No. 307, pp. 413-450.

Clarke, G. (1995), "More evidence on income distribution and growth", Journal of Development Economics, Vol. 47, pp. 403-427.

Conway, P. et. al. (2006), "Regulation, competition and productivity convergence", OECD Economics Department Working Papers, No. 509.

Cournede, B. A. Goujard, A. Pina and A. de Serres (20130, "Choosing fiscal consolidation instruments compatible with growth and equity", OECD Economics Department Policy Paper No. 7, OECD Publishing, Paris.

De Serres, A. and F. Murtin (2013) "Do policies that reduce unemployment raise its volatility?", OECD Economics Department Working Papers No. 1020, OECD Publishing, Paris.

Deininger, K. and L. Squire (1998), "New ways of looking at old issues: inequality and growth", Journal of Development Economics, Vol. 57, pp. 259-287.

Dickens, R., S. Machin and A. Manning (1999), "The effects of minimum wages on employment: Theory and evidence from Britain", Journal of Labor Economics, Vol. 17, No. 1, pp. 1-22.

DiNardo, J., N.M. Fortin and T. Lemieux (1996), "Labor market institutions and the distribution of wages, $1973-$ 1992: A Semiparametric Approach", Econometrica, Vol. 64, No. 5, pp. 1001-1044.

Dollar, D. and A. Kraay (2001), "Growth is good for the poor", Policy Research Working Papers No. 2587, The World Bank.

Dollar, D., T. Kleineberg and A. Kraay (2013), "Growth still is good for the poor", Policy Research Working Paper No. 6568, The World Bank.

Easterly, W. (2001), "The middle class consensus and economic development", Journal of Economic Growth 6(4): 317-35.

Ebenstein, A. et al. (2009), "Estimating the impact of trade and offshoring on American workers using the current population surveys", NBER Working Papers, No. 15107, National Bureau of Economic Research.

Economic Policy, Vol. 23, No. 56, pp. 601-649.

Feenstra, R. and G. Hanson (2003), "Global production sharing and rising inequality: A survey of trade and wage", in E.K. Choi and J. Harrigan (eds.), Handbook of International Trade, Malden, Blackwell, MA, pp. 146-185. 
Figari, F., A. Paulus, H. Sutherland, P. Tsakloglou, G. Verbist and F. Zantomio (2012), "Taxing home ownership: distributional effects of including net imputed rent in taxable income, EUROMOD Working papers No. EM $4 / 12$.

Fiori, G., G. Nicoletti, S. Scarpetta and F. Schiantarelli (2007), "Employment outcomes and the interaction between product and labor market deregulation: Are they substitutes or complements?", IZA Discussion Papers, No. 2770, Institute for the Study of Labor (IZA).

Forbes, K. (2000), "A reassessment of the relationship between growth and inequality", American Economic Review, Vol.90, No.4, pp. 869-887.

Foster, J. E. and M. Szekely (2008), "Is economic growth good for the poor? Tracking low incomes using general means", International Economic Review, Vol. 49, No. 4, pp.1143-1172.

Foster, J. E., S. Seth, M. Lokshin and Z. Sajaia (2013), A Unified approach to measuring poverty and inequality: theory and practice. The World Bank, Washington.

Fournier, J.-M. and I. Koske (2012), "Equality and growth - Are they compatible? Part 7. the drivers of labour earnings inequality - An analysis based on conditional and unconditional quantile regressions", OECD Economics Department Working Papers, No. 930, OECD Publishing, Paris.

Galor, O. and O. Moav (2004), "From physical to human capital accumulation: Inequality and the process of development", Review of Economic Studies 71, pp. 1001-1026.

Glaeser, E., J. Scheinkman and A. Shleifer (2003). "The injustice of inequality," Journal of Monetary Economics Vol. 50(1), pp. 199-222.

Griffith, R., R. Harrison and G. Macartney (2007), "Product market reforms, labour market institutions and unemployment", Economic Journal, Vol. 117.

Guadalupe, M. (2007), "Product market competition, returns to skill, and wage inequality", Journal of Labor Economics, Vol. 25, No. 3, pp. 439-474.

Hijzen, A. (2007), "International outsourcing, technological change, and wage inequality", Review of International Economics, Vol. 15, No. 1, pp. 188-205.

Immervol, H, H. Jacobsen Kleven, K. Thustrup Kreiner and E. Saez (2007), "Welfare reform in European countries: a microsimulation analysis", Economic Journal, Vol. 117, pp. 1-44.

Immervol, H. and C. O Donoghue (2009), "Towards a multi-purpose framework for tax-benefit micro-simulation: lessons from EUROMOD", International Journal of Micro Simulation , Vol. 2 (2), pp. 43-54.

Jara, H. X (2013), "Tax-benefit systems, income distribution and work incentives in the European Union", International Journal of micro simulation, Vol. 6 (1), pp. 27-62.

Jaumottte, F. S. Lall and C. Papageorgiou (2008), "Rising income inequality: technology, trade and financial globalisation?", IMF Working Paper, WP/08/185.

Johannsson, A and E. Olaberria (2014), "Long-term Patterns of trade and specialisation", OECD Economics Department Working Papers, forthcoming.

Joumard, I.,M. Pisu and D. Bloch (2012), "Tackling income inequality: the role of taxes and transfers", OECD Journal: Economic Studies, Vol. 2012, OECD Publishing, Paris.

Karabarbounis, L. and B. Neiman (2012), "Declining labour shares and the global rise in corporate savings", NBER Working Paper series No. 181154.

Karabarbounis, L. and B. Neiman (2013) "The global decline of the labour share", NBER Working Paper series No. 191136, forthcoming in the Quarterly Journal of Economics. 
Kluve, J. (2010), "The effectiveness of European active labour market programmes", Labour Economics, Vol. 17, Issue 6, pp. 904-918.

Koeniger, W., M. Leonardi and L. Nunziata (2007), "Labor market institutions and wage inequality", Industrial and Labor Relations Review, Vol. 60. No. 3, pp. 340-356.

Koske, I., J. Fournier and I. Wanner (2012), "Less income inequality and more growth - Are they compatible? Part 2. The distribution of labour income", OECD Economics Department Working Papers, No. 925, OECD Publishing, Paris.

Lee, D.S. (1999), "Wage inequality in the US during the 1980s: Rising dispersion or falling minimum wage?", Quarterly Journal of Economics, Vol. 114, No. 3, pp. 941-1023.

Lucas, R.E. (1988), "On the mechanics of economic development", Journal of Monetary Economics, 22.

Lundberg, M. and L. Squire (2003), "The simultaneous evolution of growth and inequality", The Economic Journal, Vol. 113, No. 487, pp. 326-344.

Mankiw, G., D. Romer and D. Weil (1992), "A contribution to the empirics of economic growth", Quarterly Journal of economics, Vol. 107, No.2, pp. 407-437.

Neumark, D. and W. Wascher (2007), "Minimum wages and employment”, IZA Discussion Papers, No. 2570.

Nickell, S., L. Nunziata, and W., Ochel W. (2005), "Unemployment in the OECD since the 1960s. What Do We Know?", Economic Journal, 115(500), pp. 1-27.

Nicoletti G, A. Bassanini, E.Ernst, S. Jean, P. Santiago and .Swaim, (2001), "Product and labour markets interactions in OECD countries", OECD Economics Department Working Papers, No. 312, OECD Publishing, Paris.

Nicoletti, G. and S. Scarpetta (2003), "Regulation, productivity and growth: OECD evidence", Economic Policy, 36 (April), OECD Publishing, Paris.

Nicoletti, G. and S. Scarpetta (2005), "Product market reforms and employment in OECD countries", OECD Economics Department Working Papers, No. 472, OECD Publishing, Paris.

Nunziata, L. ( 2002), "Unemployment, labour market institutions and shocks", Economics Papers, 2002- W16, Economics Group, Nuffield College, University of Oxford.

OECD (2003), The sources of economic growth in OECD countries, OECD Publishing, Paris.

OECD (2008), Growing Unequal? Income distribution and poverty in OECD countries, OECD Publishing Paris.

OECD (2010), Economic Policy Reforms: Going for Growth, OECD Publishing, Paris.

OECD (2011a), How's Life? Measuring well-being, OECD Publishing, Paris.

OECD (2011b), Divided We Stand: Why Inequality Keeps Rising, OECD Publishing, Paris.

OECD (2012), Economic Policy Reforms: Going for Growth, OECD Publishing, Paris.

OECD (2013a), Economic Policy Reforms: Going for Growth, OECD Publishing, Paris.

OECD (2013b), Taxing Wages 2013, OECD Publishing, Paris.

Perotti, R. (1993). "Political equilibrium, income distribution, and growth", Review of Economic Studies 60, pp. 755-776.

Persson, T. and G. Tabellini (1994), "Is inequality harmful for growth?", American Economic Review, Vol. 84, pp. $600-621$ 
Piketty, T. (2013), Le capital au XXlème siècle, ed. Seuil, Paris.

Quinet, A. and N. Ferrari (2008), Report de la commission "Mesure du pouvoir d'achat des ménages", Report submitted to Madame Lagarde, Ministry of Economy, Finance and Employment, 6 February 2008, France.

Ravallion, M. (2012), "Why don't we see poverty convergence?", American economic Review, 102 (1), pp. $504-$ 523.

Ravallion, M. and S. Chen (1997), "What can new survey data tell us about recent changes in distribution and poverty?" World Bank Economic Review Vol. 11, pp. 357-82.

Ruiz, N. and A. Trannoy (2008), 'Le caractère régressif des taxes indirectes : les enseignements d'un modèle de micro simulation", Économie et Statistique, N. 413, pp. 21-46.

Stiglitz, J.E., A. Sen and J.-P. Fitoussi (2009), Report by the Commission on the Measurement of Economic Performance and Social Progress.

Stojanovska, N. and L. Cuyvers (2010), "The interplay between international trade and technological change and the wage inequality in the OECD countries", FIW Working Paper, No. 43.

Thoenig, M. and T. Verdier (2003), "A theory of defensive skill-biased innovation and globalization", American Economic Review, Vol. 93, No. 3, pp. 709-728.

Timmer, P. (1997), "How well do the poor connect to the growth process?" CAERII Discussion Paper No. 17, HIID, Harvard.

Vanhoudt, P. (1997), "Do labor market policies and growth fundamentals matter for income inequality in OECD countries?", IMF - Staff Papers, Vol. 44, No. 3, pp. 356-373.

Voitchovsky, S. (2005), "Does the profile of income inequality matter for economic growth?", Journal of Economic Growth, Vol. 10, pp. 273-296.

Working Party No. 2 on tax policy analysis and statistics, "New approaches to economic challenges. Tax design for inclusive and sustainable economic growth in OECD countries: a scoping note", Paper discussed at WP2 Meeting 19-21 November 2013. 